\title{
Government without land
}

How will the world cope with the rash of new nations? Israel's tentative scheme for the West Bank, which proposes separate governments and separate taxes in the same land, will not often work.

WHETHER the peace conference that opened in Madrid two weeks ago will settle the Middle East's old scores is far from clear, but some of Israel's early talk of how the West Bank may eventually be administered will be taken seriously in other troubled regions. The notorious difficulty in what used to be Palestine is that both Jewish and Arab people assert equal and conflicting claims to live there. Israel has therefore been canvassing the notion that national sovereignty might be divorced from the ownership of the land. The idea is that both Palestinians and Israelis would continue to live in the disputed territories, but that their interests would be watched over by separately elected governments to which they would presumably separately pay taxes. Only the negotiations that lie ahead will tell whether such a scheme is workable in the region for which it is intended, but it is bound to excite the interest of the clutch of emergent states whose ambitions for independence are compromised by ethnic and cultural disunity.

Yugoslavia is the obvious, but not the only, case. The immediate cause of the conflict in Croatia is given as the presence there of a substantial Serbian minority, but Serbia itself is embarrassed by a substantial minority of mostly Muslim Albanians. Georgia, in the old Soviet Union, has a similar problem, as has Azerbaijan, while the cultural minorities in the Russian Federation proper, many of them arbitrarily contrived (as by Stalin's expulsion of Tartars from the Crimea) will yet come to haunt $\mathrm{Mr}$ Boris Yeltsin and his successors. Yet there are other examples of states divided within themselves that are now so familiar that the parallels are easily overlooked. Belgium is now a loose federation of two states divided on language grounds, Britain's Northern Ireland is potentially another, while South Africa's apartheid regime, now mercifully on the way out, was justified as a means of allowing different peoples to coexist.

None of this is encouraging. Although the Frenchspeaking (Walloon) community in Belgium has been for decades less well-off than the Dutch-speaking community, the differences now are not so great that coexistence is a strain. The South African experiment shows that glaring economic disparities (in that case linked to the partition of the land) make stability impossible. In any case, such schemes will function only if sovereignty is constrained. Separate community governments within a single state are usually prevented at their constitution from making common cause with outside governments; separate Protestant and Catholic governments in Northern Ireland would be politically unacceptable (to the Protestants) if the Catholic government were free to throw in its lot with the Irish Republic to the south, while the economic differences that have grown up with several decades of religious discrimination would not thereby vanish. On the face of things, the Israeli scheme for the West Bank could be made to work only if there were a new state, separate from Israel proper, and a mechanism for redistributing wealth as it is earned between two poor communities, one poorer than the other. Would Israel go that far?

For the rest, the only workable ways of coexistence for interpenetrating distinct communities must be old-fashioned ways. The general alarm about the emergence of small states in Central Europe (west of the Urals) and the Baltic can be dealt with only on the basis that the civil liberties of all who live within a state's boundaries are effectively guaranteed. Luckily, the emerging states are all de facto signatories of the Helsinki accords of 1978, which commit them to enlightened policies of civil rights. Is it not time to back these promises with enforcement? And might not the European Communities' attempt to mediate in Yugoslavia have been more successful if means of enforcing fair play were already in force?

\section{Death of a tycoon}

Robert Maxwell's death last week will engender mixed passions in the scientific community, as elsewhere.

Mr Robert Maxwell, the publishing tycoon who died last week, had been an important influence on the business of science since the early $1960 \mathrm{~s}$. He was one of the first to recognize that the Soviet Union was bursting with excellent science. His Pergamon Press performed an important public service by translating into English many important Russian works, the influential textbooks of Landau and Lifshitz, for example. Maxwell was also a prolific creator of new scientific journals, some of which (Tetrahedron, for example) have excellent reputations. But Maxwell had kleptomaniac tendencies and started or acquired many journals that are undistinguished. And he did not die a scientific publisher; he sold his Pergamon Press to the Netherlands company Elsevier (which has since also acquired the Lancet) only a few weeks before his death.

Maxwell will be remembered differently by different 